\title{
Työelämää käsittelevä oral history -konferenssi Walesissa
}

\author{
Oral History @ Work: Recording Change in Working Lives, 5.7.-6.7.2019, \\ Swansea University, Wales
}

Maria Vanha-Similä

$\mathrm{T}$ ällä kertaa Oral History Societyn vuosittainen konferenssi järjestettiin Swansean yliopistossa Walesissa. Teemana oli Oral History @ Work: Recording Change in Working Lives. Edellisen kerran konferenssi järjestettiin Swanseassa vuonna 1980. Teemana tuolloin olivat kaivostyöläiset. Lähes neljäkymmentä vuotta myöhemmin Walesissa puhuttiin edelleen paljon työväenluokkaisesta työstä ja työntekijöistä. Ja vieläkin runsaasti niistä kaivostyöläisistä.

\section{Työläisten kehot ja kieli}

Kaksipäiväinen konferenssi oli täynnä mielenkiintoista ohjelmaa. Konferenssin avasi skotlantilaisen Strathclyden yliopiston professori Arthur Mclvorin keynote-luento "Industrial Work and the Body: Toxic Legacies, Illness and Disability Stories". Mclvor kuvasi puheenvuorossaan kiinnostavasti kehon ja työn kiinteää suhdetta sekä työläismiesten kehojen altistamista ammattitaudeille. Tässäkin puheenvuorossa esimerkkinä olivat kaivosmiehet. Mclvor käsitteli toisen maailmansodan jälkeisiä vuosikymmeniä oral history -aineistojen valossa. Hän kuvasi, miten fyysinen työ oli tärkeä osa näiden työväenluokkaisten miesten identiteettiä ja maskuliinisuutta. Työnantajat pyrkivät ottamaan kaiken irti työntekijöiden kehoista. Työ vei monelta kaivosmieheltä terveyden ja erityisesti keuhkot olivat kovilla kaivostyössä. Työntekijät kertoivat työnantajien kommentoineen näitä yleisiä tapauksia usein seuraavasti: "Kaivostyö on hyväksi sinulle", "valkoinen asbesti ei ole vaarallista" tai "tupakointi tuhosi keuhkosi, ei kaivospöly". Työ oli miehille erittäin tärkeää, vaikka se vaikutti terveyteen merkittävällä tavalla. Etenkin nuoremmat miehet vaaransivat terveytensä raskaassa kaivostyössä. Kaivostoiminnan päättyminen oli suuri isku monilla alueilla. Työttömyys näille kaivosmiehille oli vaikea ja hankalasti käsiteltävä asia. Kova fyysinen työ oli ollut kunniaksi työntekijälle. Kun tietoisuus ammattitaudeista levisi ja työntekijöiden oikeudet paranivat, samaan aikaan monet kaivosmiehet joutuivat huonontuneen terveytensä kanssa kilometritehtaalle, kun työt kaivosteollisuudessa loppuivat kokonaan tai vähenivät merkittävästi.

Aivan keynote-luennon lopuksi yleisöstä esitettiin kysymys, jota jäin pohtimaan koko konferenssin ajaksi. Se koski englannin kieltä. Konferenssi oli englanninkielinen ja suurin osa osallistujista oli Iso-Britanniasta ja muista englanninkielisistä maista. Mukana oli myös meitä, 
joiden äidinkieli ei ollut englanti, vaan pyrimme tulemaan sillä toimeen parhaan kykymme mukaan. Tällä matkalla kiinnitin kuitenkin erityisen paljon huomiota kieleen. Walesilaiset olivat erittäin ystävällisiä ja heidän kanssaan tuli helposti juttuun. Juna- ja bussimatkat menivät paikallisten kanssa keskustellessa. Välillä jouduin melkoisesti pinnistelemään, jotta pysyin kärryillä. Murre oli etenkin vanhemmilla ihmisillä toisinaan niin voimakas.

Esitelmiä kuunnellessa ja keskustellessa toisten osallistujien kanssa, puheesta sai yleensä aika mukavasti selvää. Paneeleissa esitetyillä ääninauhoilla esiintyi useasti työväenluokkaisia miehiä ja naisia. Ilman litteraatiota minulta olisi mennyt aika monta juttua ohi. Keskustelin aiheesta myös muutamien englantia äidinkielenään puhuvan osallistujan kanssa. He tunnustivat, että myös heillä oli todellisia vaikeuksia saada selvää esimerkiksi skottilaisten työläisten puheesta. Tämä oli huojentavaa, mutta samalla palasin tuohon englannin kieltä koskevaan kysymykseen. Mclvorilta nimittäin kysyttiin luentonsa päätteeksi, miten oli mahdollista saada vastauksia yliopistoissa käytetyllä ylemmän keskiluokan englannilla esimerkiksi skotlantilaisilta työläisiltä. Miten tutkija ymmärtäisi tutkimuskohdettaan ja saisi haastateltavan avautumaan, kun puhuttu kieli ja maailmat olivat niin erilaiset. Tähän ei tullut kovin tyhjentävää vastausta. Oral history -tutkimuksessa kieli ja puhe ovat kaiken avain. Brittein saarilla englanti on yhteinen kieli, mutta samalla hyvin erottava tekijä. Kun joku alkaa puhua, toiset laittavat hänet heti oikeaan lokeroonsa. Puhuttu kieli paljastaa paljon.

Paljon puhuvan kielikeskustelun pohjalta jäin pohtimaan puhuttua kieltä myös Suomen muistitietohankkeissa ja -tutkimuksissa. Tutkija ja haastateltava saavat yleensä selvää toistensa puheesta, mutta mitä jää ymmärtämättä, kysymättä tai vastaamatta, kun kieli ja tapa puhua eroavat.

\section{Kiinnostavien puheenvuorojen runsautta}

Toisen keynote-luennon piti Beth Thomas National Museum Walesista aiheenaan "When Work is History and History is Work: Museums, Oral Testimonies and Authenticities". Thomasilla on takanaan pitkä museoura. Hän kuvasi, miten museot ovat hyödyntäneet suullista muistitietoa sekä miten tämä on muuttunut viimeisen 40 vuoden aikana. Museot ovat pitkään keskittyneet luonnollisesti esineisiin, mutta oral history auttaa ymmärtämään esinemaailmaa, menneisyyttä ja identiteettiä. Monella museolla on tässä vielä petrattavaa, kehitettävää ja opittavaa oral history -tutkimuksen mahdollisuuksista.

Kolmas ja viimeinen keynote-luento, "After Coal: Welsh and Appalachian Mining Communities", käsitteli jälleen kaivosyhteisöjä. Dokumenttielokuvaohjaaja ja professori Tom Hansell Yhdysvalloista kuvasi After Coal -nimistä oral history -hanketta, jossa tarkasteltiin kahta entistä kaivosyhteisöä. Toinen niistä sijaitsi Etelä-Walesissa, toinen Yhdysvalloissa. Hankkeessa tarkasteltiin yhteisöjen yhtäläisyyksiä ja eroavaisuuksia. Hanke tuotti runsaasti videomateriaalia. Siinä pyrittiin myös edistämään työväenluokkaisten yhteisöjen sopeutumista jälkiteolliseen aikaan. Paluuta entiseen ei ole vaan kaivoksista eläneiden yhteisöjen tulee löytää uudelleen paikkansa, järjestää työtä ja elämisen mahdollisuuksia.

Konferenssissa oli useita mielenkiintoisia työryhmiä. Työtä ja työntekijöitä käsiteltiin monesta eri näkökulmasta. Yhtä aikaa pidetyistä sessioista oli välillä vaikea valita. Niin osuvia puheenvuoroja olisi ollut tarjolla, mutta samaan aikaan ei voinut olla monessa paikassa. Antoisa oli esimerkiksi työryhmä "Oral Histories at the National Railway Museum: 
Collecting, Researching and Exhibiting the Oral Histories of Working Lives". Paneeli sisälsi neljä puheenvuoroa siitä, miten muistitietohankkeita toteutetaan ja hyödynnetään kansallisessa rautatiemuseossa.

Kiinnostavaa oli kuulla esimerkiksi Britannian raideliikenteen yksityistämisestä nousseista hankkeista. Edelleen pääpaino oli työntekijöissä, mutta vähitellen tutkimuskohteeksi on otettu myös matkustajat ja aikanaan yksityistämistä vastustaneet kansanliikkeet. Kiinnostavaa oli myös, miten suullinen muistitieto tuo uutta tietoa jo tunnetusta aiheesta. Esimerkiksi toisen maailmansodan aikana naisia työskenteli Britannian rautateillä, kun miehiä oli runsaasti rintamalla. Tästä on kirjallisesta aineistoa, mutta muistitieto toi tutkijoille aivan uutta näkökulmaa naisten sodanaikaiseen työskentelyyn rautateillä: mitä he oikeastaan tekivät, miten sen kokivat ja miten heihin suhtauduttiin.

Hedelmällisiä työryhmiä olivat samoin siirtolaisuutta, naisten työssäkäyntiä ja perhettä koskevat keskustelut. Oma puheenvuoroni oli työryhmässä "Work and Family", jossa käsiteltiin erityisesti työn ja isyyden problematiikkaa toisen maailmansodan jälkeen. Alistair Thomson kuvasi tilannetta Australiassa, Richard Hall Britanniassa ja minä Suomessa. Kaikkialla miehet kertoivat tutkijoiden tekemissä haastatteluissa arjestaan yleensä työkeskeisesti. Naisilla oli päävastuu lastenhoidosta, mutta yllättävät tilanteet, kuten isän työttömyys tai vanhempien siirtyminen vuorotyöhön, muuttivat perheiden roolijakoja. Yhdistävät ja erottavat tekijät saivat aikaan kiinnostavan keskustelun.

\section{Summa summarum}

Konferenssi oli innostava, kiinnostava ja monipuolinen. Koin koko ajan olevani aivan oikeassa paikassa, mikä on aika harvinaista. Tutkimusintressini istuivat kuin nakutettu konferenssin teemaan. Oli hienoa kohdata tutkijoita, jotka toteuttivat mitä erilaisempia oral history -tutkimushankkeita. Olin ilahtunut myös museoiden ja arkistojen innokkaasta osallistumisesta. Käytännönläheiset puheenvuorot toivat kuvauksia hankkeiden arkisesta toteutuksesta akateemisten pohdintojen lomassa.

Konferenssissa puhuttiin paljon fyysisestä työväenluokkaisesta työstä. Kaivosmiehet olivat esillä monessa puheenvuorossa. Välillä tuntui, että edellisestä Swanseassa vuonna 1980 järjestetystä konferenssista teemat eivät ole kovin laajentuneet. Tämä on tietysti kärjistetty kiteytys, mutta jäin kaipaamaan lisää puheenvuoroja muunkinlaisesta työstä. Viime vuosikymmeninä työ on muuttunut merkittävästi. Toisaalta voinw ymmärtää hyvin lähihistoriaan keskittyneet teollisuusyhteisöjä käsittelevät oral history-projektit. Ne ovat olleet paikallisesti erittäin tärkeitä. Ne ovat auttaneet käsittelemään suuria muutoksia, kuten raskaan teollisuuden vähentymistä länsimaissa ja siten työpaikkojen katoamista. Projektit ovat tukeneet, kun tehdasyhteisöt ovat muuttuneet historiaksi ja kulttuuriperinnöksi ja ovat joutuneet pyristelemään eteenpäin muuttuvassa maailmassa. Oral history -projektit ovat vahvistaneet paikallista identiteettiä, kun teollisuuden voimalla eläneet paikkakunnat ovat joutuneet etsimään uudelleen paikkaansa tehtaiden suljettua ovensa.

Monessa esitelmässä käytettiin ääntä tai videoklippejä. Ne elävöittivät puheenvuoroja merkittävästi. Toisinaan samaan esitelmään oli laitettu hyvin monia katkelmia. Ne tekivät esitelmistä melko levottomia. Esimerkit vain seurasivat irrallisina toisiaan, mutta yhteenveto tai 
ajatus jäi vähän hataraksi. Toisaalta myös näin oral history -tutkimuksen ydin, haastateltavien oma ääni, nousi esitelmissä keskiöön.

Wales on kaunis ja sieltä löytyy kaikkea. Kaupunkeja, maaseutua, merta ja vuoristoa. Walesissa olisi viihtynyt pidempäänkin. Konferenssi-illallinen järjestettiin National Waterfront Museumissa. Tämä tarjosi mahdollisuuden samalla tutustua Swansean tärkeimpään museoon ja sen näyttelyihin. Konferenssin kanssa samaan aikaan paikkakunnalla järjestettiin myös Walesin suurin vuosittainen tapahtuma, The Wales Airshow. Konferenssivieraiden oli mahdollista ihailla huikaisevan hienoja lentonäytöksiä tiiviiden konferenssipäivien lomassa.

Ensi vuonna konferenssi järjestetään Bournemouth Universityssä Etelä-Englannissa. Teemana tulee olemaan Oral history and the media.

Filosofian tohtori Maria Vanha-Similä työskentelee näyttelyamanuenssina Suomen maatalousmuseo Sarassa ja tekee väitöksen jälkeistä tutkimusta naisten arjesta. 